\title{
Tomato and Nightshade (Solanum nigrum L. and S. ptycanthum Dun.) Effects on Soil Water Content
}

\author{
Milton E. McGiffen, Jr. ${ }^{1}$ \\ Illinois Natural History Survey, Champaign, IL 61820
}

\author{
John B. Masiunas ${ }^{2}$ \\ Department of Horticulture, University of Illinois, 1201 W. Gregory Drive, Urbana, IL 61801 \\ Morris G. Huck \\ U.S. Department of Agriculture-Agricultural Research Service, Crop Protection Research Unit, \\ Urbana, IL 61801
}

Additional index words. weed competition, fruit quality, biomass partitioning, water stress, processing tomato,
Lycopersicon esculentum, irrigation

\begin{abstract}
Field and greenhouse experiments were conducted to determine the response of eastern black nightshade (Solanum ptycanthum), black nightshade (S. nigrum), and tomato (Lycopersicon esculentum Mill. cv. Heinz 6004) to water stress and the effect of nightshade-tomato competition on soil water content. In the greenhouse, plants were exposed to three water regimes induced by watering either daily, weekly, or biweekly. Water deficit caused a similar decrease in height, weight, and leaf area in all three species. There was more than a $50 \%$ reduction in height when the plants were watered biweekly compared with daily watering. Water stress caused a shift in biomass from shoots to roots in all three species. Black nightshade and tomato produced thinner leaves in response to water deficit. Companion field experiments were conducted during the 1989 and 1990 growing seasons in Urbana, Ill. Eastern black nightshade and black nightshade were transplanted at densities of $0.8,1.6,3.2$, and 4.8 plants $/ \mathrm{m}^{2}, 5$ days after tomatoes were transplanted. These nightshade densities caused significant reductions in soil water content. In 1989, only the highest density of either nightshade species reduced topsoil water content. In 1990, all densities of nightshade, except the two lowest densities of black nightshade, reduced topsoil water content. Eastern black nightshade consistently had a greater effect on tomato yield than black nightshade. Tomato yields averaged over both years were 17,000 and $8,000 \mathrm{~kg} \cdot \mathrm{ha}^{-1}$ at the highest $\left(4.8 \mathrm{plants} / \mathrm{m}^{*}\right)$ density of black and eastern black nightshade, respectively. The decrease in soil moisture from high densities of nightshade could not account for the reduced yields.
\end{abstract}

Precise water management is critical for successful production of processing tomatoes. Tomato vegetative and fruit growth is very sensitive to water stress (Sanders et al., 1989; Wudiri and Henderson, 1985). Vegetative growth is affected by closure of stomates, leaf rolling, and shifts in assimilate partitioning induced by water stress. When soil water is abundant, the bulk of the assimilated $\mathrm{C}$ is partitioned to the shoots, but when water is limiting, roots receive more assimilate (Geddes et al., 1979). The leaves of tomato cultivars such as 'Saladette' roll their leaves under high evaporative demand and thereby escape severe water stress (Wudiri and Henderson, 1985). Rudich et al. (1981) reported that tomatoes close their stomates at a water deficit of -6 bars, reducing water loss and $\mathrm{C}$ assimilation at moderate levels of water stress.

Reproduction is generally the most water-stress sensitive of tomato growth stages (Wudiri and Henderson, 1985). Water stress during fruiting affects fruit quality and yield. Adequate soil moisture during flowering, fruit set, and fruit development is critical for maximum tomato yields (Rudich et al., 1977;

Received for publication 5 Sept. 1991. Accepted for publication 24 Feb. 1992. Mention of a trademark or proprietary product does not constitute a guarantee or warranty of the product by the Illinois Natural History Survey, the Univ. of Illinois, or the USDA and does not imply its approval to the exclusion of other products that may also be suitable. The cost of publishing this paper was defrayed in part by the payment of page charges. Under postal regulations, this paper therefore must be hereby marked advertisement solely to indicate this fact.

'Current address: Dept. of Botany and Plant Sciences, Univ. of California, Riverside, CA 92521

${ }^{2}$ To whom reprint requests should be addressed.
Wudiri and Henderson, 198.5). Water stress during these growth stages results in fruit failing to develop adequate size (Cannel1 and Asbell, 1974; Moore et al., 1957; Rudich et al., 1977; Sanders et al., 1989). Excessive moisture during fruit development increases foliar diseases and fruit rots (Geisenberg and Stewart, 1986; Rudich et al., 1977). Tomato fruit quality is improved with moderate water stress because the total and soluble solid concentrations (SSC) are increased (Geisenberg and Stewart, 1986; Mitchell et al., 1991; Rudich et al., 1977; Sanders et al., 1989; Vittum et al., 1961). The increased SSC results from lower water accumulation by the fruit (Mitchell et al., 1991; Vittum et al., 1961).

Water management also affects weed interference. Many weeds can adapt to grow under a wide range of soil moisture conditions (Nadeau and Morrison, 1986). Weed root growth is often rapid, allowing the weeds to exploit soil water reserves held in large soil volumes (Davis et al., 1967). For example, common cocklebur (Xanthium strumarium L.) exploits the water reserves held in a large soil volume, thus gaining a competitive advantage over soybean [Glycine max (L.) Merr.] (Geddes et al., 1979). But water stress also can shift competition to favor the economic crop. Patterson (1988) reported that water stress reduced spurred anoda [Anoda cristata (L.) Schlecht.] and velvetleaf (Abrutilon theophrasti Medik.) biomass, thus increasing the competitiveness of cotton.

Eastern black nightshade and black nightshade can significantly reduce tomato yields (McGiffen, 1991; Perez and Masiunas, 1990; Weaver et al., 1987). The critical period for

Abbreviation: WAP, weeks after planting. 
nightshade interference in tomato is 4 to 8 weeks after crop establishment (Perez and Masiunas, 1990; Weaver, 1984; Weaver and Tan, 1983). This critical phase coincides with the full bloom stage of tomato (Freisen, 1979; Perez and Masiunas, 1990). Tomato yield reduction from nightshade interference is primarily due to shading effects (Weaver and Tan, 1983). If nightshade emerges after tomato, nightshade produces thin shade leaves with less mesophyll (McGiffen et al., 1992). These adaptations increase light use efficiency when nightshades grow under the crop canopy (Stoller and Myers, 1989). The thinner leaves also result in a lower water-use efficiency (Yun and Taylor, 1986). Nightshades compete for the soil moisture available to the crop. Thus, at lower soil water potentials, tomato stomatal conductance and transpiration rates are reduced (Weaver, 1984).

Irrigation schemes for tomatoes have not taken water use from weed interference into account (Al-Jibury and May, 1969; Geisenberg and Stewart, 1986; Rudich et al., 1977; Sanders et al., 1989). Although nightshade interference has a significant impact on tomato yield, we found no literature documenting the effect of that interference on soil water content. Thus, the objective of this study was to determine the relative response of nightshade and tomato to water stress and their effect on soil water content.

\section{Materials and Methods}

Effect of water regime on growth (greenhouse experiment). A greenhouse experiment was conducted to characterize the response of eastern black nightshade, black nightshade, and the processing tomato cultivar Heinz 6004 to water regimes. The three species were sown separately in 4-liter pots containing 1 peat : 1 perlite : 1 loam soil (by volume). The seedlings were thinned to one plant per pot 2 weeks after emergence.

Sunlight was supplemented by artificial lighting provided by mercury vapor lamps with an intensity of $200 \mathrm{pmol} \cdot \mathrm{m}^{-2} \cdot \mathrm{s}^{-1}$ at the plant canopy. The photoperiod was $16 \mathrm{~h}$ day/8 h night, and the relative humidity was $78 \% \pm 12 \%$. The greenhouse was at a $24 \pm 3 \mathrm{C} / 18 \pm 2 \mathrm{C}$ day/night cycle.

Treatments consisted of three moisture regimes: watering daily, weekly, or biweekly. At each watering, the pots were watered until no further water was absorbed. Water content of the pots ranged from $22 \%$ to $70 \%$ by weight. The treatments were initiated 3 weeks after emergence, when the plants had two to four true leaves. There were two cycles ( 2 weeks each) of drought stress. In the first cycle, wilting occurred only in the biweekly treatment. In the second cycle, wilting occurred 5 days after watering. A solution of $0.2 \mathrm{M}^{`} \mathrm{KNO}_{3}, 0.02 \mathrm{M} \mathrm{KH}_{2} \mathrm{PO}_{4}$, and 0.05 $\mathrm{M} \mathrm{KC1}$, resulting in a final concentration $\left(\mu \mathrm{g} \cdot \mathrm{ml}^{-1}\right)$ of $210 \mathrm{~N}$, $31 \mathrm{P}$, and $234 \mathrm{~K}$ was applied every 2 nd week to all treatments. The experiment was a randomized complete block with four replications and was repeated.

Plants were harvested 7 weeks after emergence. Shoot height was measured just before harvest of fruit. After harvest, the plants were divided into leaf, stem, and root tissue. Leaf area was determined using a LI-COR 3100 leaf area meter (LI-COR, Lincoln, Neb.). Dry weights of leaves, stems, and roots were determined by drying the tissue for 5 days at 70C. Specific leaf area, an indicator of leaf thickness, was determined by dividing leaf area by leaf weight.

Effect of nightshades on soil water content, photosynthesis, and yield (field experiment). Five-week-old 'Heinz 6004' processing tomato transplants were planted in Urbana, Ill., on 23 May 1989 and 18 May 1990. The site is flat, with minimal slope. Plots were $2.7 \times 5.7 \mathrm{~m}$ and included three rows of 12 tomato plants each. Tomato spacing was $45 \mathrm{~cm}$ within the row and $90 \mathrm{~cm}$ between rows. The soil type was a Flanagan silt loam (fine montmorillontic, mesic, Aquic Argiudoll) with 4\% to $5 \%$ organic matter and a $\mathrm{pH}$ of 6.2 . The field capacity was $41 \%$ and wilting point $13 \%$ (J. Wang and M.G. Huck, unpublished data). Urea was applied at a rate of $240 \mathrm{~kg} \cdot \mathrm{ha}^{-1}$ before both seasons. Trifluralin at $0.8 \mathrm{~kg}$ a.i./ha was incorporated into the soil before planting to control weeds other than nightshade. After tomatoes were established, weeds that emerged were removed by hand.

There were nine tomato-nightshade intercrop treatments, consisting of a control (tomatoes with no nightshade) and either black or eastern black nightshade planted into the tomato rows at densities of $0.8,1.6,3.2$, or 4.8 nightshade plants $/ \mathrm{m}^{*}$. Nightshades were established as two-leaf transplants when tomatoes had recovered from transplanting ( 5 days after tomatoes were planted). The experiment was a randomized complete block with five replications.

Neutron probe access tubes were installed immediately after incorporation of trifluralin and before planting of tomatoes. As the access tubes were installed, soil core samples were removed at $15-\mathrm{cm}$ increments to a depth of $150 \mathrm{~cm}$ to allow gravimetric determination of soil water content. Initial neutron probe measurements were recorded as the tubes were installed to allow calibration against gravimetric water content values determined from the core samples. Additional gravimetric samples from 15 $\mathrm{cm}$ increments to a depth of $150 \mathrm{~cm}$ were taken during the 2nd week of July, after significant drying of subsurface horizons had occurred.

Throughout both growing seasons, neutron probe readings were taken at $30-\mathrm{cm}$ increments down to $150 \mathrm{~cm}$ below the soil surface. The neutron probe readings were taken immediately before or 3 days after each rainfall or irrigation. Rainfall was supplemented with sprinkler irrigation to provide an average of $25 \mathrm{~mm}$ water/week, according to standard practices (Lorenz and Maynard, 1980). There was no wilting of tomato or nightshade plants. No irrigation or rainfall occurred during the 7th or 10th weeks after planting (WAP) in either year (Table 1). The total amount of water depleted from the soil each year was determined as the difference between the maximum and minimum soil water content readings.

To determine if eastern black nightshade, black nightshade, or tomato differed in their physiological responses to moisture

Table 1. Weekly rainfall and irrigation at Urbana, Ill., during the 1989 and 1990 growing seasons.

\begin{tabular}{lcc}
\hline \hline WAP & $\begin{array}{c}1989 \\
(\mathrm{~mm})\end{array}$ & $\begin{array}{c}1990 \\
(\mathrm{~mm})\end{array}$ \\
\hline 1 & 59 & 30 \\
2 & 24 & 6 \\
3 & 3 & 50 \\
4 & $40^{* \mathbf{z}}$ & 32 \\
5 & 98 & 80 \\
6 & 4 & 43 \\
7 & 0 & 0 \\
8 & $40^{*}$ & 52 \\
9 & 41 & 29 \\
10 & 0 & 0 \\
11 & $40^{*}$ & $40^{*}$ \\
12 & 0 & 19 \\
13 & 2 & 0 \\
Total & 351 & 381 \\
\hline
\end{tabular}

$\mathrm{z}$ *Denotes $40 \mathrm{~mm}$ water applied using sprinkler irrigation. 
stress, photosynthetic rate and stomata1 conductance were measured weekly from the 4th through the 11th WAP. Measurements were taken at 1100-1300 HR solar time on clear days when solar irradiance at the leaf level was $>1600 \mu \mathrm{mol} \cdot \mathrm{m}^{-2} \cdot \mathrm{s}^{-1}$. Recently fully expanded leaves of each species were measured in situ with a LI-COR 6200 closed portable photosynthesis system with a 4liter chamber. Two readings per species were taken from plants in the center row of each plot, and the data were averaged.

During week 13, tomato fruits were harvested by hand from the center row of each plot and weighed. More than $60 \%$ of the tomatoes in the control plots were at the pink stage of ripeness (Manley, 1983) when harvested. A random sample of 50 fruits from each plot was weighed to determine individual fruit weight. The sample was then graded according to U.S. Dept. of Agriculture (USDA) standards (Manley, 1983), and the percentages of USDA no. 1, green, and rotted tomatoes were determined.

Data from both experiments were tested using analysis of variance. Interactions with repeats (greenhouse) or years (field) were determined, and where possible data were combined. When significant treatment differences occurred, the means were separated using the least significant difference procedure. Photosynthetic and yield data were subjected to regression analysis.

\section{Results and Discussion}

Effect of water regime on growth (greenhouse requriment). Eastern black nightshade, black nightshade, and tomato responded similarly to water stress. A decrease in watering frequency decreased the dry weight, height, and leaf area of all three species (Table 2 ). Across all watering regimes, black nightshade was the tallest, had the largest leaf area, and was the heaviest of the three species. When watered daily, mean heights were 53,34 , and $38.5 \mathrm{~cm}$ for black nightshade, eastern black nightshade, and tomato, respec-

Table 2. Effect of watering frequency on the height, biomass, and leaf area of black nightshade, eastern black nightshade, and tomato in the greenhouse experiment. Results are the average of two experiments.

\begin{tabular}{|c|c|c|c|c|}
\hline \multirow{2}{*}{$\begin{array}{l}\text { Plant } \\
\text { characteristic }\end{array}$} & \multicolumn{3}{|c|}{ Watering frequency } & \multirow[b]{2}{*}{$\operatorname{LSD}_{0.0}$} \\
\hline & Daily & Weekly & Biweekly & \\
\hline \multicolumn{5}{|l|}{$\mathrm{Ht}(\mathrm{cm})$} \\
\hline Black nightshade & 53.3 & 36.0 & 22.8 & 4.5 \\
\hline Eastern black & 34.0 & 23.0 & 14.8 & 2.9 \\
\hline Tomato & 38.5 & 24.5 & 18.9 & 2.6 \\
\hline \multicolumn{5}{|l|}{ Leaf wt $(\mathrm{g})$} \\
\hline Black nightshade & 6.55 & 3.83 & 1.93 & 0.42 \\
\hline Eastern black & 5.25 & 4.03 & 1.80 & 0.60 \\
\hline Tomato & 6.30 & 3.52 & 1.52 & 0.83 \\
\hline \multicolumn{5}{|l|}{ Stcm wt $(\mathrm{g})$} \\
\hline Black nightshade & 4.85 & 2.15 & 1.03 & 0.51 \\
\hline Eastern black & 3.18 & 2.22 & 0.82 & 0.37 \\
\hline Tomato & 4.58 & 1.95 & 0.78 & 0.59 \\
\hline \multicolumn{5}{|l|}{ Root wt (g) } \\
\hline Black nightshade & 3.20 & 2.18 & 1.30 & 0.72 \\
\hline Eastern black & 1.65 & 1.00 & 1.00 & 0.64 \\
\hline Tomato & 2.45 & 1.68 & 1.02 & 0.29 \\
\hline \multicolumn{5}{|l|}{ Leaf area $\left(\mathrm{cm}^{2}\right)$} \\
\hline Black nightshade & 1530 & 910 & 615 & 128 \\
\hline Eastern black & 1800 & 1210 & 593 & 119 \\
\hline Tomato & 1330 & 888 & 398 & 227 \\
\hline \multicolumn{5}{|l|}{$\begin{array}{l}\text { Specific leaf area } \\
\left(\mathrm{cm}^{2} \cdot \mathrm{g}^{-1}\right)\end{array}$} \\
\hline Black nightshade & 234 & 238 & 320 & 19.4 \\
\hline Eastern black & 344 & 300 & 330 & 28.8 \\
\hline Tomato & 211 & 252 & 260 & 26.0 \\
\hline
\end{tabular}

tively. When watered biweekly, there was $>50 \%$ reduction in height for all three species.

Water regime also affected biomass production. Total biomass production for black nightshade watered daily was $14.6 \mathrm{~g}$ but only $4.25 \mathrm{~g}$ when watered biweekly. There was no effect of water regime on the portion of biomass allocated to leaves. All three species increased the percentage of biomass in the roots as watering frequency decreased. Averaged over all three species, when the plants were watered daily, $20 \%$ of the biomass was allocated to roots; $30 \%$ of the biomass was allocated to the roots when the plants were watered biweekly.

Across all watering regimes, tomatoes had the least and black nightshade had the most leaf area per unit land area. In each species, leaf area decreased as the water deficit increased. Specific leaf area of black nightshade and tomato increased as the frequency of watering decreased. This result indicates that black nightshade and tomatoes responded to a reduction in watering frequency by growing thinner leaves, in contrast to the increased leaf thickness reported for species adapted to water stress (Yun and Taylor, 1986). We observed no increase in the specific leaf area of eastern black nightshade as the frequency of watering decreased.

Effect of nightshades on soil water content, photosynthesis, and yield field experiment). The overall amount of moisture supplied to the crop was similar in both years (Table 1). Less rainfall fell during Summer 1989 than in 1990; thus, irrigation was required during 3 weeks of the 1989 growing season but only during 1 week of the 1990 season. Forty-five percent of the total volume of water added to the soil during the 1989 growing season came from irrigation, but only $10 \%$ of the water needed to replace losses came from irrigation in 1990. About $60 \%$ of the total was added during the first 7 weeks of the growing season each year, before tomato flowering began. Soil water content of the upper and lower strata declined from 5 WAP through harvest (12 WAP in 1989, 11 WAP in 1990); when measured, soil water content was lower than at any time during the growing season (Fig. 1).

The heaviest rainfall (wettest week of the growing season) occurred 5 WAP in both 1989 and 1990 (Table 1). There was a substantial increase in soil water content at 5 WAP in 1989 for both the topsoil ( 0 to $60 \mathrm{~cm}$, Fig. 1) and the subsoil (60- to $150-\mathrm{cm}$ soil depths, Fig. 2), indicating that a large portion of the $98 \mathrm{~mm}$ of rain that fell that week had percolated downward through the soil profile. Because this rain fell as several showers instead of a single rainfall event, runoff was minimal. However, during the 1990 growing season, most of the rain that fell 5 WAP was in a single event lasting $<4 \mathrm{~h}$, which saturated the soil surface before moisture could percolate down into the deeper soil layers. Although not measured in 1989 or 1990, runoff was only observed during this rainfall event.

Nightshade competition influenced topsoil water content (Fig. 1). In 1989, the first significant differences in topsoil water content between treatments occurred 9 WAP, while in 1990, the first differences were at $6 \mathrm{WAP}$, since the season began with significantly lower subsoil water reserves (Fig. 2). Nightshade density did not cause a significant difference in subsoil water content $(<60 \mathrm{~cm})$ in either year.

The treatments that caused significant reductions in topsoil water content also differed between years. In 1989, significant differences in soil water content resulted from variation in weed density, regardless of whether the species was black or eastern black nightshade. In 1990 , the lower density $\left(1.6\right.$ plants $\left./ \mathrm{m}^{2}\right)$ of black nightshade had no effect on topsoil water content (com- 


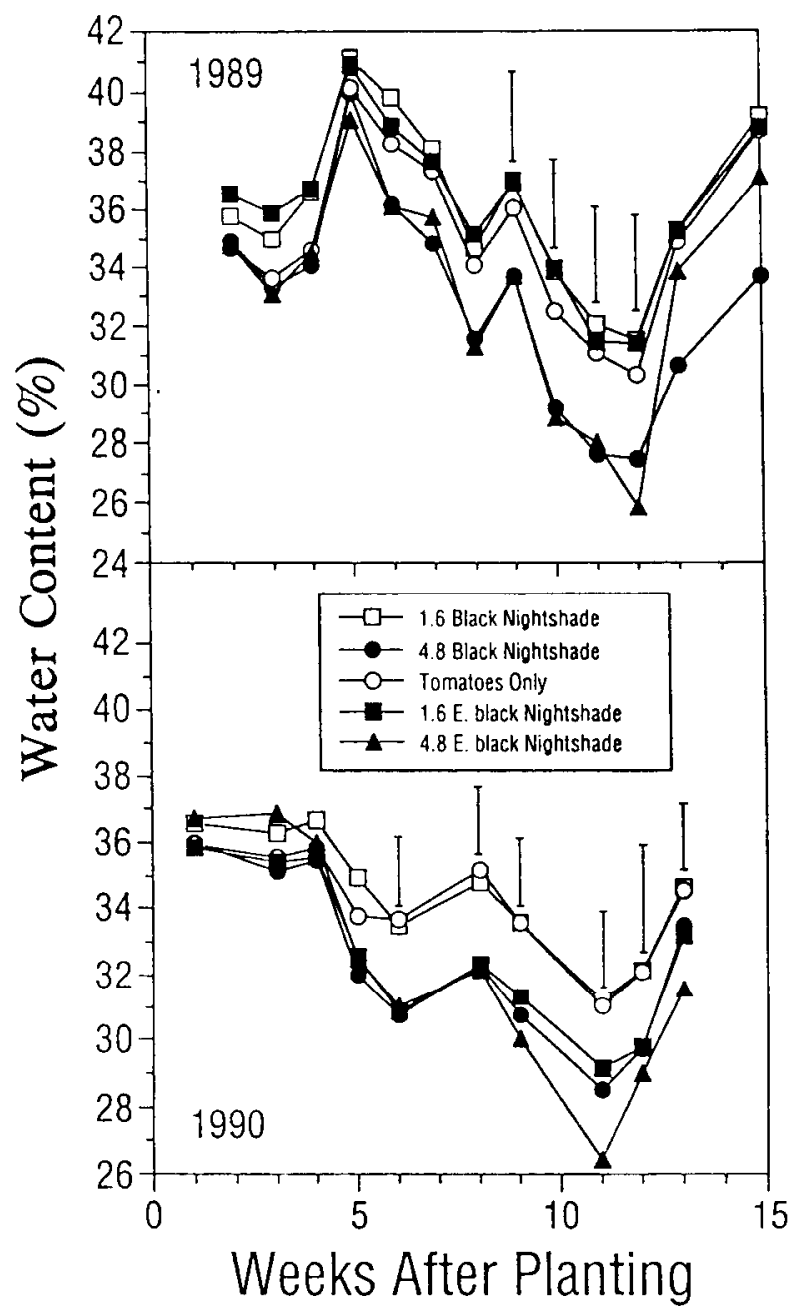

Fig. 1. Water content (percent by volume) of topsoil (upper $60 \mathrm{~cm}$ ) of tomato plots with various nightshade densities. The vertical bars represent confidence limits with a significance of $P \leq 0.05$. Time points without bars did not have significant differences in soil water content between treatments. Top, 1989, bottom, 1990 growing seasons.

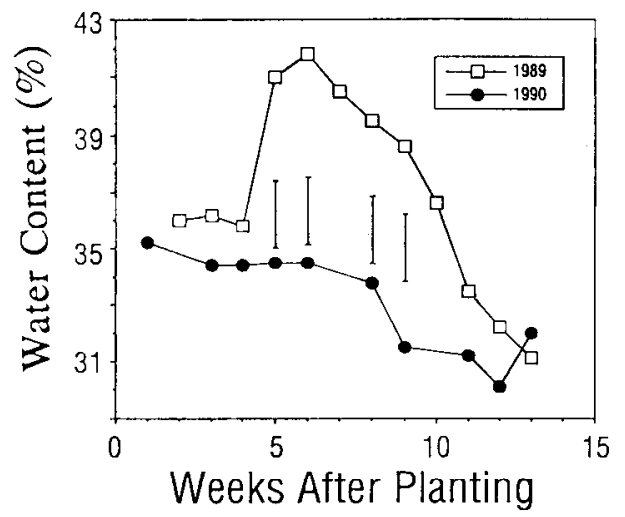

Fig. 2. Mean water content (percent by volume) of subsoil (60-150$\mathrm{cm}$ depth). There was no effect of nightshade density on subsoil water content. The vertical bars represent confidence limits with a significance of $P \leq 0.05$. Time points without bars were not significantly different.

pared with weed-free control plots). Compared with the weedfree control, soil water content was lower in the highest density of both nightshade species through the mature green stage of tomatoes (10 WAP), and for 4.8 eastern black nightshade plants/ $\mathrm{m}^{2}$ through 13 WAP.

Due to a higher initial soil water content, nearly twice as much water was depleted from the profile in 1989 as in 1990 (data not shown). Soil water extraction patterns are indicative of rooting depth and distribution (Ristaino and Duniway, 1991; Taylor and Klepper, 1976), so more roots may have been concentrated in the upper $60 \mathrm{~cm}$ of the profile in 1990 than in 1989. The possible higher concentration of roots in a smaller volume of soil during 1990 may explain why nightshade competition caused a decline in tomato quality and number of green fruits in 1990 but not in 1989. Cannel and Asbel (1974) also found that late-season declines in soil water content resulted in fewer green fruit but had no effect on marketable yield.

Photosynthetic rate was related to stomatal conductance (Fig. 3). Black nightshade responded to increased stomatal conductance by assimilating $\mathrm{C}$ more quickly than either tomato or eastern black nightshade. Photosynthetic rates for eastern black nightshade and tomato were relatively insensitive to changes in stomatal conductance. Tomato photosynthetic rates ranged from 10 to $40 \mu \mathrm{mol} \mathrm{CO}_{2} / \mathrm{sec}$ per $\mathrm{m}^{2}$. The range of photosynthetic rates for tomato was less than the range measured for black nightshade but was similar to those of eastern black nightshade.

Black nightshade density did not affect total tomato yield (USDA no. 1 and greens) in 1989. Eastern black nightshade and black nightshade decreased total yield (Fig. 4). In both years, yield declined linearly with eastern black nightshade density. Eastern black nightshade consistently had a greater effect on yield than black nightshade. For example, in 1989, 19,000 and $9000 \mathrm{~kg}$ fruit/ha were harvested in plots containing 4.8 plants $/ \mathrm{m}^{2}$ of black or eastern black nightshade, respectively.

In 1989, nightshade density did not have a significant effect on tomato grades. But in 1990, black or eastern black nightshade density affected fruit quality, increasing the percentage of USDA no. 1 fruit (Fig. 5). However, eastern black nightshade consistently resulted in more green tomato fruit than black nightshade.

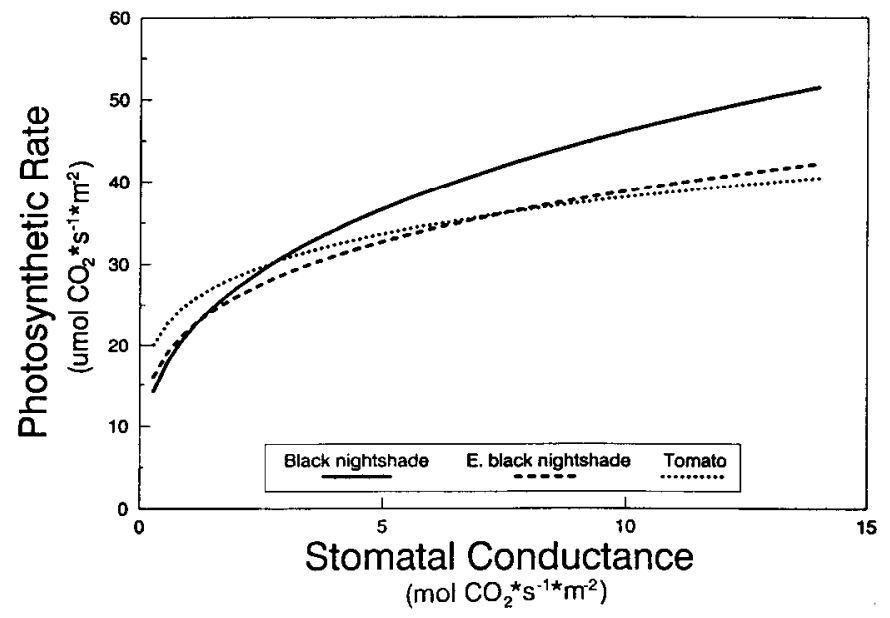

Fig. 3. Relation between stomatal conductance and $\mathrm{CO}_{2}$ fixation rate of black nightshade, eastern black nightshade, or tomato. Each equation is the result of $>100$ data points from the combined 1989 and 1990 results. The regression equations are: black nightshade, Photosynthetic rate $=21.5$ (Stomata1 Conductance) ${ }^{0.33}, r^{2}=0.54$; eastern black nightshade, Photosynthetic rate $=21.9$ (Stomata1 Conductance) ${ }^{0.25}, r^{2}=0.39$; and tomato, Photosynthetic rate $=$ 25.08 (Stomata1 conductance) ${ }^{0.17}, r^{2}=0.32$. The equations were significant at $P \leq 0.05$. 


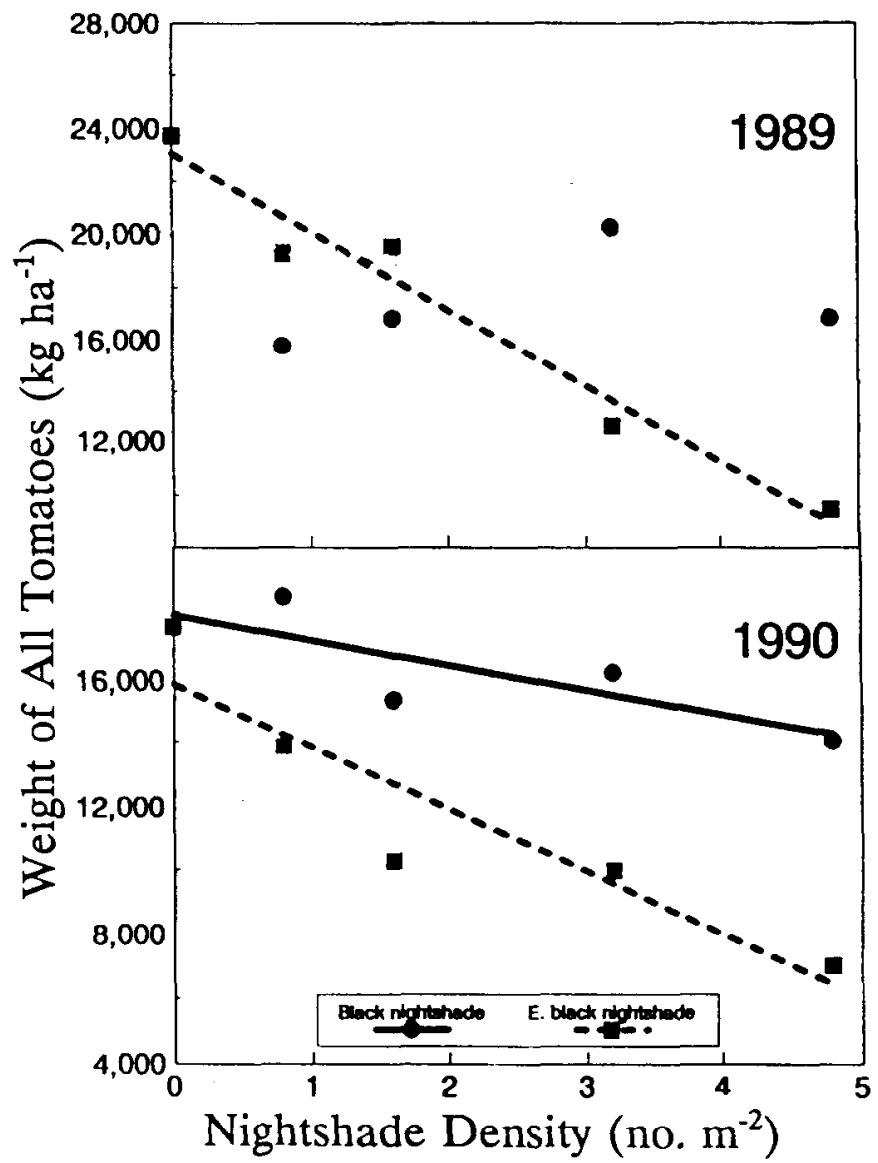

Fig. 4. Total weight of all classes of tomatoes (including USDA no. 1 , greens, and rotten) as a function of nightshade density. The regression equations are for 1989: black nightshade, no significant regression; eastern black nightshade, Yield $=23,000-2,930$ (no./ $\left.\mathrm{m}^{2}\right), r^{2}=0.96$. In 1990, the regression equations are: black nightshade, Yield $=17,800-758\left(\right.$ no. $\left./ \mathrm{m}^{2}\right), r^{2}=0.69$; eastern black nightshade, Yield $=15,800-1,950\left(\right.$ no. $\left./ \mathrm{m}^{2}\right), r^{2}=0.86$. The equations were significant at $P \leq 0.05$.

The decrease in soil moisture from high densities of nightshade caused no measurable water stress in tomatoes. Tomato stomata1 conductance was the same across all treatments, and there were no treatment effects on water content in the deeper soil profiles $(60$ to $1.50 \mathrm{~cm})$. Further, although the effect of eastern black nightshade on soil water content was equivalent to the effect of the highest density of black nightshade, only eastern black nightshade decreased tomato yield in both years.

We therefore conclude that the primary cause of tomato yield loss from weed interference is shading (Friesen, 1979; McGiffen, 1991; Weaver and Tan, 1983). Eastern black nightshade shades tomatoes for more of the critical reproductive stage than does black nightshade (McGiffen, 1991). Eastern black nightshade also is better adapted to compete for light because its specific leaf area increases more rapidly than that of black nightshade (McGiffen, 1991), thus increasing photosynthetic efficiency when shaded. Our results did not show significant competition of nightshades with tomatoes for water.

The tomato growth stage during which soil moisture is reduced from weed interference may be important in determining the impact of competition for moisture on crop yield. Soybeans are most vulnerable to competition with velvetleaf early in the season, before the crop's root system has fully developed (Munger et al., 1987). Late-season water stress caused three times

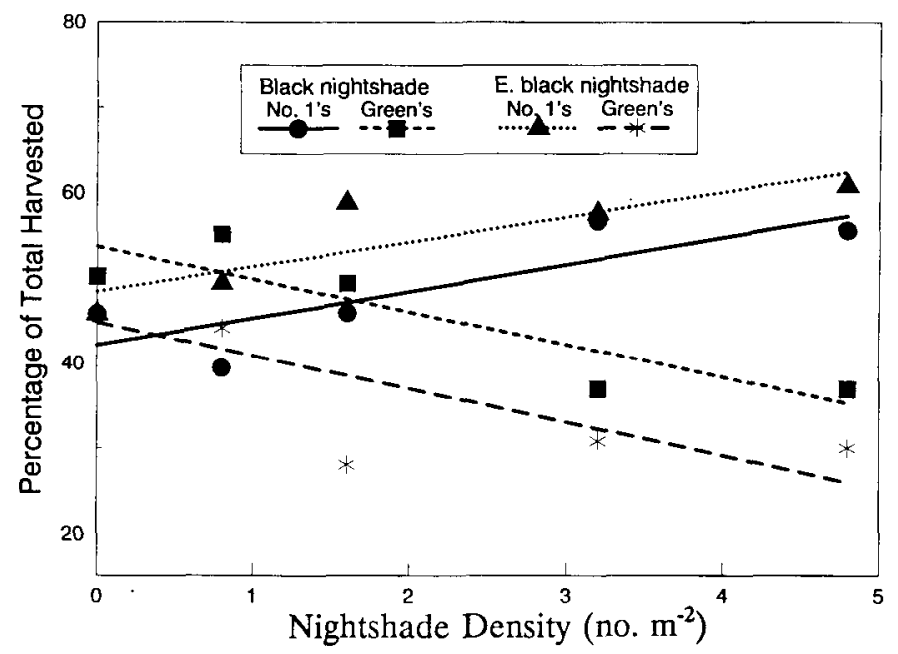

Fig. 5. Effect of nightshade density on the percentage of tomatoes graded as USDA no. 1 or green. Only 1990 data are presented, because in 1989 , nightshade density did not have a significant $(P \leq$ $0.05)$ effect on grades. The regression equations are: 1) the effect of black nightshade on percent no. 1 's, $\mathrm{Y}=42.1+3.17\left(\right.$ no. $\left./ \mathrm{m}^{2}\right)$, $\left.r^{2}=0.69 ; 2\right)$ the effect of black nightshade on percent green, $\mathrm{Y}=$ $53.7-3.84\left(\right.$ no. $\left.\left./ \mathrm{m}^{2}\right), r^{2}=0.79 ; 3\right)$ the effect of eastern black nightshade on percent no. 1 's, $\mathrm{Y}=48.4+2.91\left(\mathrm{no} . / \mathrm{m}^{2}\right), r^{2}=$ 0.74 ; and 4) the effect of eastern black nightshade on percent green, $\mathrm{Y}=44.8-3.92\left(\right.$ no. $\left./ \mathrm{m}^{*}\right), 9=0.58$.

as much yield loss from yellow foxtail competition with soybeans than when drought occurred at other times in the growing season (Nadeau and Morrison, 1986). In our study, reductions in soil moisture from nightshade interference occurred after flowering, with the largest differences observed after the mature-green stage. Most of the yield in processing tomatoes is derived from pollination during the first 15 days of flowering (Rudich et al., 1977). This period precedes the time nightshade reduced soil moisture in our study.

Modifications in cultural practices may reduce or eliminate competition for soil moisture. Transplanting, for example, gives tomatoes an initial size advantage over the nightshade. Initial size of the co-occurring species is an important determinant of competition (Alm et al., 1991). The initial size advantage of tomatoes may have delayed the onset of differences in soil water content due to the treatments until late in the season, after much of the yield is determined. The use of trickle irrigation and plastic mulches could also affect the ability of weeds to compete for soil moisture.

Reductions in soil water content from weed interference may be important when light does not limit tomato growth. Transplanted tomatoes in the reproductive stage of growth have $85 \%$ of their roots in the upper $30 \mathrm{~cm}$ of the soil (Portas and Dordio, 1980), where reductions in soil water content from nightshade interference occur. This could make tomatoes extremely sensitive to competition for moisture. The potential susceptiblity may be overcome by developing tomato cultivars that maximize wateruse efficiency, produce dense canopies, and develop root systems rapidly.

\section{Literature Cited}

Al-Jibury, F.D. and D. May. 1970. Irrigation schedules and production of processing tomatoes on the San Joaquin Westside. Calif. Agr. 24:10-11.

Aim, D.M., M.E. McGiffen, Jr., and J.D. Hesketh. 1991. Modelling 
weed phenology, p. 143-167. In: T. Hodges (ed.). Physiological aspects of predicting phenology. CRC, Boca Raton, Fla.

Cannell, G.H. and C.W. Asbell. 1974. Irrigation of field tomatoes and measurement of soil water changes by neutron moderation methods. J. Amer. Soc. Hort. Sci. 99:305-308.

Davis, R.G., W.C. Johnson, and F.O. Wood: 1967. Weed root profiles. Agron. J. 59:555-556.

Freisen, G.H. 1979. Weed interference in transplanted tomatoes ( $L y$ copersicon esculentum). Weed Sci. 27:11-13.

Geddes, R.D., H.D. Scott, and L.R. Oliver. 1979. Growth and water use of common cocklebur (Xanthium pensylvanicum) and soybeans (Glycine max) under field conditions. Weed Sci. 27:206-212.

Geisenberg, C. and K. Stewart. 1986. Field crop management, p. 511557. In: R.G. Atherton and J. Rudich (eds.). The tomato crop. Chapman and Hall, New York.

Lorenz, O.A. and D.N. Maynard. 1980. Knott's handbook for vegetable growers. 2nd ed. Wiley, New York.

Manley, W.T. 1983. United States standards for grades of tomatoes for processing. U.S. Dept. Agr. Mktg. Serv., Washington, D.C.

McGiffen, Jr., M.E. 1991. The environmental physiology of tomato (Lycopersicon esculentum Mill cv. Heinz-6004) and black or eastern black nightshade (Solanum nigrum L. and S. ptycanthum Dun.) competition. PhD Diss., Univ. of Illinois, Champaign.

McGiffen, Jr., M.E., J.B. Masiunas, and J.D. Hesketh. 1992. Competition for light between tomatoes and nightshades (Solanum nigrum or S. ptycanthum). Weed Sci. 40:220-226.

Mitchell, J.P., C. Shennan, S.R. Grattan, and D.M. May. 1991. Tomato fruit yields and quality under water deficit and salinity. J. Amer. Soc. Hort. Sci. 116:215-221.

Moore, J.N., A.A. Kattan, and J.W. Fleming. 1957. Effect of supplemental irrigation, spacing, and fertility on yield and quality of processing tomatoes. Proc. Amer. Soc. Hort. Sci. 71:356-368.

Munger, P.H., J.M. Chandler, J.T. Cothren, and F.M. Hons. 1987. Soybean (Glycine mar)-velvetleaf (Abutilon theophrasti) interspecific competition. Weed Sci. 35:647-653.

Nadeau, L.B. and I.N. Morrison. 1986. Influence of soil moisture on shoot and root growth of green and yellow foxtail (Setaria viridis and S. lutescens). Weed Sci. 34:225-232.

Patterson, D.T. 1988. Growth and water relations of cotton (Gossypium hirsutum), spurred anoda (Anoda cristata), and velvetleaf (Abutilon theophrasti) during stimulated drought and recovery. Weed Sci. 36:318-324

Perez, F.G.M. and J.B. Masiunas. 1990. Eastern black nightshade
(Solanam ptycathum) interference in processing tomato (Lycopersicon esculentum). Weed Sci. 38:385-388.

Portas, C.A.M. and J.J.F.B. Dordio. 1980. Tomato root system, a short review with reference on tomatoes for processing. Acta Hort. 100:113-124.

Ristaino, J.B. and J.M. Duniway. 1991. The impact of phytophthora root rot on water extraction from soil by roots of field-grown processing tomatoes. J. Amer. Soc. Hort. Sci. 116:603-608.

Rudich, J., D. Kalmar, C. Geizenberg, and S. Harel. 1977, Low water tensions in defined growth stages of processing tomato plants and their effects on yield and quality. J. Hort. Sci. 52:391-399.

Rudich, J., E. Rendon-Poblete, M.A. Stevens, and A.I. Ambri. 1981. Use of leaf water potential to determine water stress in field-grown tomato plants. J. Amer. Soc. Hort. Sci. 106:732-736.

Sanders, D.C., T.A. Howell, M.M.S. Hile, L. Hodges, D. Meek, and C.J. Phene. 1989. Yield and quality of processing tomatoes in response to irrigation rate and schedule. J. Amer. Soc. Hort. Sci. 114:904-908.

Stoller, E.W. and R.A. Myers. 1989. Response of soybeans and four broadleaf weeds to reduced irradiance. Weed Sci. 37:570-574.

Taylor, H.M. and B. Klepper. 1976. Water uptake by cotton root systems: An examination of assumptions in the single root model. Soil Sci. 120:57-67.

Vittum, M.T., W.B. Robinson, and G.A. Marx. 1961. Raw product quality of vine-ripened processing tomatoes as influenced by irrigation, fertility level, and variety. Proc. Amer. Soc. Hort. Sci. 80:535543.

Weaver, S.E. 1984. Critical period of weed competition in three vegetable crops in relation to management practices. Weed Res. 24:317325.

Weaver, SE. and C.S. Tan. 1983. Critical period of weed interference in transplanted tomatoes (Lycopersicon esculentum): growth analysis. Weed Sci. 31:476-481.

Weaver, S.E., N. Smits, and C.S. Tan. 1987. Estimating yield losses of tomatoes (Lycopersicon esculentum) caused by nightshade (Solanum spp.) interference. Weed Sci. 35:163-168.

Wudiri, B.B. and D.W. Henderson. 1985. Effects of water stress on flowering and fruit set in processing-tomatoes. Scientia Hort. 27:189198.

Yun, J.I. and SE. Taylor. 1986. Adaptive implications of leaf thickness for sun- and shade-grown Abutilon theophrasti. Ecology 67:13141318. 